\title{
ADMINISTERING UNEMPLOYMENT COMPENSATION BENEFIT CLAIMS
}

\author{
WALTER F. DODD*
}

The discussion in this article is based on the assumptions that state laws may constitutionally be enacted to conform to the Federal Social Security Act and that this act will be held to be a valid exercise of Congressional power. Nothing herein is to be construed as expressing concurrence either with the federal legislation or with the assumption that it is constitutional. The only issue here discussed is that as to methods of administration of state laws. This primarily involves the organization for the purpose of administering the law, and the procedure from the time a claim is filed under the law, although the problems of administration cannot, of course, be severed from the substantive provisions of law that are to be administered.

The form of administrative organization is, of course, conditioned by the task to be performed. The things to be done with respect to unemployment compensation are in many respects similar to those in workmen's compensation, and it is therefore to be expected that the administrative organization and procedure should be in large part copied from workmen's compensation laws. But in the enactment of the new laws, the legislatures are not disturbed by certain problems which faced the draftsmen of the original workmen's compensation laws, and are in a position to profit by experience in the administration of such laws. It is natural, therefore, to find in the unemployment compensation laws no use of trial by jury, and greater use of finality of fact determination by administrative bodies. It is natural also to find repeated the provisions of workmen's compensation laws as to compulsion to produce testimony, self-incrimination, the avoidance of technical rules of evidence and of procedure, and judicial review of administrative determinations.

In both unemployment compensation and workmen's compensation there is (I) a large task of administrative supervision which may be termed ministerial in character; (2) the examination and approval or disapproval of the great bulk of claims where there will be no contest of the claim or of the action denying a claim; the problem here is largely ministerial, but involves also a wide discretionary power, and

- A.B., I898, Florida State College; B.S., I gor, Stetson University; Ph.D. 1905, University of Chicago. Member of the Illinois Bar. Engaged in the practice of law in Chicago. In charge of an investigation of the administration of workmen's compensation acts for the Commonwealth Fund, the results of which are in course of publication. Author of treatises in the fields of constitutional law, state government, and appellate jurisdiction and practice. 
the proper exercise of this power will diminish the number of contested claims; (3) the determination of contested claims. In workmen's compensation, the most satisfactory procedure with respect to contested claims has been that of an initial administrative hearing, with a review on appeal by some body or person who did not participate in or have an interest in the decision resulting from the initial hearing. Finality of fact-determination by administrative bodies is proper where adequately safeguarded, but such adequate safeguard requires that there be both an administrative hearing and a possibility of administrative review, before appeal may be had to the court on issues of law.

The most essential point in any scheme of unemployment compensation is that of investigation of claims that are not contested; the next most essential point is that of the initial hearing upon a contested claim. The great bulk of claims will not be contested; and the decision on the initial hearing will in fact be final as to the great majority of claims that are contested. The initial investigation and allowance of uncontested claims will be much more important in unemployment compensation than in workmen's compensation. In workmen's compensation there is an employeremployee relationship, and, except under exclusive state funds, an adversary relation exists between the employee on the one side and the employer or insurance carrier on the other. The issues of contest are more clearly defined under workmen's compensation; a claim is uncontested only when there appears no ground for contest; and no claim is settled without some investigation by a directly interested person or corporation. Unemployment compensation, on the other hand, will in most cases stand more nearly in contrast with workmen's compensation under an exclusive state fund, as in Ohio, where there is no specific and direct interest upon the part of the employer. But the workmen's compensation issues even under an exclusive state fund are more specific, and merit rating gives some specific interest to the employer. Yet experience during a period of depression has shown that the exclusive state fund under workmen's compensation is not sufficiently protected.

Whatever may be the defects of the system of employer reserves ${ }^{1}$ adopted in Wisconsin and Utah, and to some extent in Oregon, there remains under such laws a specific liability which may afford more ample protection to a fund as contrasted with the state-wide pooled fund. Pecuniary interest presents the strongest means of assuring that improper claims or improper amounts of claims are not allowed. This pecuniary incentive in Wisconsin and Utah may be restricted and the adoption of the pooled fund may be forced by refusal to permit adequate credit of employers' contributions against the tax imposed by the Federal Social Security Act. If the power of Congress to adopt the Social Security Act is sustained, the character of the state law will be completely within federal control. The laws that have adopted the single pooled plan (except the New York act, the first to adopt this plan) provide, it is true, for ratings of employers in I94I and thereafter on the basis of unemployment

${ }^{1}$ This system is discussed in Brandeis, The Employer Reserve Type of Unemployment Compensation Law, supra, p. 54 . 
experience, ${ }^{2}$ but the value of such provisions as a means of protecting the fund is doubtful, in view of the experience with merit rating in Ohio. The employeremployee relation is not directly maintained, and although notice of action upon the employee's claim may be required to be sent to the most recent employer, the pecuniary interest is too remote to protect a public fund.

In the nature of things, unemployment compensation will promote unemployment in certain groups, just as health insurance has promoted sickness, and as workmen's compensation promotes continued disability in certain types of cases. Laws will not change human nature, but they may provide safeguards against abuses occasioned by certain types of human reactions. Where a specific employer's account is affected by a claim, as in Wisconsin and Utah, notice of a claim to the employer creates a sufficient adversary relation, and produces a contest, where the claim may be regarded as improper. Where there is a pooled fund, notice to the most recent employer will usually not create a contest even of an improper claim, and protection of a fund must be provided by some other means, if at all.

Different types of administrative organization have been adopted by the states that have enacted unemployment compensation acts. A conference of Labor Department officials held in Asheville, North Carolina, on October 5, 1935, urged the desirability "of placing the administration of state unemployment compensation in the state agency generally responsible for the administration of labor legislation." It is doubtful whether such a broad suggestion will find support. It is not possible to establish a uniform pattern for all states. ${ }^{3}$ In Alabama, California, Massachusetts and Washington, separate commissions have been established to administer unemployment compensation, and to have supervision of public employment offices; for the District of Columbia a separate board is created composed of the commissioners of the District as members ex officio, and one representative of employers and one of employees. In Oregon the members of the State Industrial Accident Commission (the body administering workmen's compensation) constitute the State Unemployment Compensation Commission which also controls free public employment offices. In Wisconsin and Utah unemployment compensation is placed under the industrial commissions which also administer the other labor laws of these states. In New Hampshire the Commissioner of Labor administers the act. In New York the administration is placed in the hands of the Industrial Commissioner, who is the head of the State Department of Labor, and a salaried state appeal board of three members is created. Provision is made generally by unemployment compensation acts for a state advisory board composed of representatives of employers, employees and of the general public, each in the same number.

Which method of organization is best must be left to future determination, and it is probable that, as in workmen's compensation, no one plan will be found to be

2 This system is discussed in Rubinow, State Pool Plans and Merit Rating, stupra, p. 65.

-For the types of organizations adopted, see Cook, The Bodies Administering Unemployment Compensation Laws, supra, p. 95. 
the best. The essential things are that there be a close correlation of the functions of investigation and of administrative adjudication; and that both the administrative responsibility and the review of administrative determinations be vested in officers or bodies not too busy to perform their duties. There has been some difficulty where administrative review is independent of the original administrative hearing and of the task of investigation. New York and Pennsylvania have such an organization for workmen's compensation, and New York now applies this plan to unemployment compensation. Such a plan, to operate successfully, requires the coopperation of the department and of the independent board, and a different type of organization may well avoid difficulties which are at times presented by the absence of such coöperation. Much may be said in favor of an independent commission administering unemployment compensation and public employment offices; though, if the burden is not too heavy, the same result of coördinated administration may be obtained by combining unemployment compensation with the administration of all other labor laws by a single commission, as in Utah and Wisconsin. Such combination, however, is likely to make an administrative review by the commission a purely perfunctory matter because the commission is too busy with other matters; under such conditions administrative review should be provided before some other body which can in fact hear the issues, and provision is so made in Wisconsin and Utah.

With respect to claims procedure, public employment offices serve as the places for registration and usually for the filing of claims, and one of the conditions for approval of state laws in order to get federal grants for the expense of administration and in order that employers may get credit against the federal tax is that provision shall be made for "payment of unemployment compensation solely through public employment offices in the state or such other agencies as the [Social Security] Board may approve." In New York the manager of the local state employment office at which the employee is registered receives the claim, sends notice to the employee's last employer, and, in accordance with rules of the Industrial Commissioner, determines the validity of the claim and the amount of benefits. ${ }^{5}$ The employee or any other party affected by the finding may apply for a hearing before the manager, and from the manager's decision on such hearing, an appeal may be taken to the state appeal board of three members, any one of whom may act for the board. ${ }^{6}$ A decision of the manager, if not appealed from, is final on all questions of fact and law, and a decision of the appeal board is final on all questions of fact, and, unless appealed from, is final on all questions of law. ${ }^{\top}$ From the appeal board an appeal on questions of law may be taken to the Appellate Division of the Third District, and an appeal may then be taken to the Court of Appeals as is provided for other civil actions. ${ }^{8}$

This outline of New York procedure indicates a broad power in the manager of

'Social Security Act of Aug. 14, 1935, Public, No. 271, 74th Cong., Ist Sess., tit. III, $\$ 303$ (a) (2), tit. IX, 5903 (a) (I).

${ }^{5}$ N. Y. Cons. Laws, c. 31, art. 18, \$510 (3) (N. Y. Laws 1935, c. 486).

'Id. \$510 (4).

"Id. $\$ 510$ (6).

${ }^{8}$ Id. $5510(7)$. 
the local state employment office. If he decides for the claimant, the decision is final if no one is sufficiently interested to appeal, and no one is likely to be sufficiently interested. No power is given to the Industrial Commissioner to question the decision unless he be a "party affected who appeared at the hearing before the manager," a construction which is doubtful. The fund is not adequately protected against improper awards, because of the absence of any person with a sufficient adversary interest to make a contest, but the employee is fully protected by provisions for appeal. A gesture of protection for the state fund appears in the provision that: "When the appeal board affirms a decision of a manager allowing benefits, such benefits shall be paid regardless of any appeal which may thereafter be taken to the courts . . . but if the said decision is finally reversed by the courts, the commissioner shall have a right of action for the recovery of the moneys paid pursuant to said decision."10

In New York, it is true, provision is made for a continuing jurisdiction in the Industrial Commissioner, upon his own initiative or upon application of any party in interest, to review an award of benefits or a denial of a claim therefor "on the ground of a change in conditions, or because of a mistake as to fact," 11 and similar provisions are found in other acts; ${ }^{12}$ but defects in the original award are not likely to be effectively checked through this power. The New Hampshire procedure is similar to that of New York. ${ }^{13}$ Under the California law, the Commission controls as to whether claims shall be filed with the manager of the public employment office for the district or with a deputy of the commission designated for the purpose, and the investigation is made by the officer with whom filed, but provision is made for direct appeal to the commission only by the claimant. ${ }^{14}$

Wisconsin, although less in need of safeguards, because of the pecuniary interest of the employer in his own reserves, has made more satisfactory provision for the initial investigation by "a deputy designated by the commission."15 Not only this, but the Commission is also given power "to remove or transfer the proceedings on any claim pending before a deputy, appeal tribunal or commissioner," with full power to alter any decision or to direct the taking of new evidence. ${ }^{16}$ A number of the other laws vest complete control in the central organization by permitting it to designate the officer to make the original investigation, and by empowering it to take control of proceedings on any pending claim. ${ }^{17}$ Such provisions are necessary if uniform and competent administration is to be had, and these provisions are much more essential where there is a pooled fund than where there is an individual employer reserve. There is no assurance that the manager of a local employment office

${ }^{8} I d$. 5510 (4). ${ }^{10} \mathrm{Ibid}$. 11 Id. $\$ 505$ (2).

${ }^{12}$ Utah Laws 1935, H. B. No. 86, \$12; cf. Ore. Law 1935, Spec. Sess., H. B. No. 7x, $\$ 9$.

${ }^{13} \mathrm{~N}$. H. Laws 1935, c. 99, $\$ \$ 30-39$. $\quad{ }^{14}$ Cal. Stat. 1935, c. 352, art. 6.

${ }^{25}$ WIs. STAT. \$108.09 (2).

${ }^{17}$ Ala. Laws 1935, Sen. B. No. 395, \$7 (a), (f); Mass. GEN LAws, c. I5IA, \$\$34, 36 (Mass. Laws 1935, c. 479); N. H. Laws 1935, c. 99, \$\$31, 35; Wash. Laws I935, c. 145, $\$ 8$ (2), (6); Wis. STAт. (1935) \$108.9 (2), (6). 
has the experience needed for the determination of claims, and his contact with other aspects of unemployment may make it undesirable to require that he be used for this purpose. Moreover, the determination of claims should not be under local control, but should be a matter of uniform state policy.

With respect to administrative hearing and review, there are some differences among the laws, all of which, however, provide or profess to provide for one original hearing and for one review by a body other than that holding the original hearing. In Utah a hearing may be had before the officer of the employment office or before a salaried umpire designated by the Commission, with an appeal to a district appeal board, and thence to a state appeal board, with the necessity then of seeking a rehearing before the Industrial Commission before review may be sought in the Supreme Court. ${ }^{18}$ This procedure, which will, of course, be used in few cases, appears to be unduly complicated, though it must be borne in mind that judicial review is directly by the highest court of the state of Utah. In Oregon, on the other hand, the original investigation may be made without hearing, and unless a rehearing is sought before the Commission, the action of the deputy or employee designated by the Commission to make such investigation "as he deems necessary," is considered the decision of the Commission. ${ }^{19}$ In Massachusetts a hearing may be demanded before the local or branch employment office official and "any party affected by such decision of the local or branch employment office official may file an appeal in such manner and within such time as the Commission may require, with such appeal board as the Commission may by rule establish for said purpose."20 This gives more discretion as to administrative organization and procedure than is usually found in state laws.

In creating original or intermediate appeal boards, the laws of Alabama, ${ }^{21}$ the District of Columbia, ${ }^{22}$ New Hampshire, ${ }^{23}$ Utah, ${ }^{24}$ Washington, ${ }^{26}$ and Wisconsin ${ }^{20}$ contain provisions which appear to be a hang-over from early compensation statutes. Appeal boards are established with a full time salaried employee as chairman, and with two other members, one representing employees and one representing em. ployers, but with provision under most of the statutes that the chairman alone may act in the absence of one or both the others, provided they had notice of the session. This recalls the theory of arbitration present in many of the early compensation laws, and still remaining in some, but of which very little use has been made in practice.

The use of lawyers or other representatives in the presentation of unemployment compensation claims involves a problem not dissimilar from that existing in workmen's compensation; the issues are less definite, but, on the other hand, are by no means so complex as those involved in contested workmen's compensation cases.

\footnotetext{
${ }^{18}$ Utah Laws 1935, H. B. No. 86, \$\$13-19. $\quad{ }^{10}$ Ore. Laws 1935, H. B. No. 7I, \$9.

20 Mass. Gen. LAws, c. I5IA, $\$ \$ 34,35$ (Mass. Laws 1935, c. 479).

${ }^{21}$ Ala. Laws r935, Sen. B. No. 395, $\$ 7 \mathrm{f}$.

${ }_{22}$ Dist. of Col., Public, No. 386, 74th Cong. Ist Sess. (1935), \$12 (d).

$\approx$ N. H. Laws 1935 , c. $99, \$ 35$.

$\approx$ Wash. Laws I935, c. $145, \$ 8(6)$.

${ }^{24}$ Utah Laws r935, H. B. No. 7r, \$9.

${ }^{20}$ WIs. STat. §I08.09 (4).
} 
Here again, the question as to the existence of an adversary relation presents itself. Aside from the states having exclusive state funds, contested workmen's compensation claims involve representation of two adverse parties. Except for the states having individual employer reserves, claims under unemployment compensation will be against a single fund, and the contest will primarily be one by the claimant against denial of an award or reduction of a claim. In such cases there will probably be much the same type of abuse as in workmen's compensation. Efforts to prevent solicitation and to avoid abuses by those representing claimants have not proved effective in workmen's compensation. Some states and many bar associations have thought they could correct the evils by limiting representation to lawyers, and the New York unemployment compensation act forbids the allowance of fees for representation unless the agent or representative is an attorney and counsellor at law. ${ }^{27}$ In theory the lawyer is better trained to handle contested claims for compensation, and, in theory also, he is subject to stricter discipline than those who are not members of the bar. But experience with workmen's compensation suggests a grave doubt as to whether lay representation of claimants is less efficient or less honest than that of the lawyer. A more direct protection to the claimant is sought through control of fees. For unemployment compensation claims, New York limits claims for services to ten per cent, and requires that such claims be approved by the Industrial Commissioner in order to be enforcible. ${ }^{28}$ Wisconsin does not go so far, but requires commission approval of fees in excess of ten per cent. ${ }^{29}$ Experience with workmen's compensation indicates that control of fees must be mandatory if it is to be effective. Solicitation is a misdemeanor under the New York act, ${ }^{30}$ but penalties alone may accomplish little toward curbing a practice which has as yet been little controlled in the field of workmen's compensation.

In the methods of administrative organization and procedure adopted by the several states will be found the influence of model unemployment compensation bills drafted in Washington. In view of the fact that it must approve the state laws, the Social Security Board has recently drafted two unemployment compensation billsone based on the pooled fund plan with merit rating, and the other on separate employer reserves but with alternative provisions for partial pooled accounts. ${ }^{31}$ The bills so drafted properly contain alternative provisions as to the form of organization for the administration of unemployment compensation. Both bills wisely follow the Wisconsin plan in providing that the original investigation shall be by "a deputy or representative designated by the commission"32 and in vesting complete supervisory control in the commission. ${ }^{33}$ The Board's drafts contemplate an administrative hearing before an appeal tribunal composed, in the discretion of the commission, of either

${ }^{27}$ N. Y. Consol. LAws, c. 3 I, art. I8, 55 II (2) (N. Y. Laws I935, c. 486 ).

${ }^{29} I d$. $\$ 511(3)$.

$\approx$ Wis. STAT. §ro8.rot.

${ }^{30}$ N. Y. Consol. Laws, stipra note $27, \$ 5 \mathrm{II}(3)$.

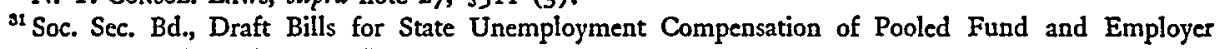
Reserve Account Types (Jan. I936).

$=1 d . \$ 6(\mathrm{~b})$.

ss Id. $\$ 6$ (c), (f). 
a salaried examiner or a commissioner or of a board of three members consisting of a salaried officer and of one representative of employers and one of employees. ${ }^{34}$ The alternative of a three-member board for such hearings is unimportant, for its use lies in the discretion of the commission, and initial hearings will in fact be held by full-time employees. Under the drafts, the initial hearing is held by the appeal tribunal and the decision of such tribunal becomes the decision of the commission and is final as to issues of fact "unless within ten days after the date of such decisions, the commission acts on its own motion or permits any of the parties to initiate further appeal or review."35 Here again the drafts follow the Wisconsin practice in that administrative review is not a matter of right but rests in the discretion of the commission; this plan has not proved unsatisfactory in the administration of workmen's compensation in Wisconsin, but where there is an adversary relation between the parties, it appears safest to have review as a matter of right if the administrative determination of fact is to be final. In practice, however, in case of contest much of the unemployment compensation will be paid on the basis of the appeal tribunal's action, by virtue of the provision that "if an appeal tribunal affirms a decision of a deputy, or the commission affirms a decision of an appeal tribunal, allowing benefits, such benefits shall be paid regardless of any appeal which may thereafter be taken, but if such decision is finally reversed, no employer's account shall be charged with benefits so paid." ${ }^{36}$ The Board's drafts are to be commended as seeking to centralize administrative control within each state.

In any discussion of state laws, attention must, of course, be given to the provisions of the Federal Social Security Act. Without the approval of a state law by the Social Security Board, no state may receive a federal grant for unemployment compensation administration, ${ }^{37}$ and no employer may receive credit against the federal tax for contributions under a state law. ${ }^{38}$ Not only must the state law be approved in first instance, but the Board has continuing authority to decline to certify any state for the federal grant or the taxpayers' credit. ${ }^{30}$ There is, therefore, a complete control by the Federal Board in the application of the standards established by federal law, and a wide discretion may be exercised as to whether such standards have in first instance been met or continue to be met by the methods of state administration. Moreover, in view of the fact that public employment offices are used under all the state laws, and were intended by the Social Security Act to be so used, ${ }^{40}$ the Department of Labor has a similar continuing supervision over employment offices under the National Employment System Act of June 6, 1933. ${ }^{41}$ But the Social Security Act is the most important. Section 303 (a) of this act provides, among other things, that the law of a state shall include provisions for:

\footnotetext{
${ }^{3} I d$. $\$ 6$ (d).
${ }^{3}$ Social Security Act, supra note I, tit. III $\$ 303$ (c).

${ }^{23}$ Id., tit. IX $\$ 902$.

${ }^{\circ}$ Id., tit. III, $\$ 303$ (a) (I), tit. IX, $\$ 903$ (a) (1).

48 STAT. II 4,29 U. S. C. A. (Supp.) c. 4 C. For a discussion of the relation of the United States Employment Service to the administration of unemployment compensation laws, see Stead, The Rôle of the Public Employment Service in the Unemployment Compensation Program, supra, p. 100.
} 
"(I) Such methods of administration (other than those relating to selection, tenure of office, and compensation of personnel) as are found by the Board to be reasonably calculated to insure full payment of unemployment compensation when due; and

(2) Payment of unemployment compensation solely through public employment offices in the State or such other agencies as the Board may approve; and

(3) Opportunity for a fair hearing, before an impartial tribunal, for all individuals whose claims for unemployment compensation are denied. ...."

Section 303 (b) provides that:

"(b) Whenever the Board, after reasonable notice and opportunity for hearing to the State agency charged with the administration of the State law, finds that in the administration of the law there is-

(I) a denial, in a substantial number of cases, of unemployment compensation to individuals entitled thereto under such law; or

(2) a failure to comply substantially with any provision specified in subsection (a); the Board shall notify such State agency that further payments will not be made to the State until the Board is satisfied that there is no longer any such denial or failure to comply. Until it is so satisfied it shall make no further certification to the Secretary of the Treasury with respect to such State."

Section 903 (a) makes a number of requirements as to the provisions of state laws, but subdivision (5) perhaps gives the broadest discretion of the Federal Board in the continuing supervision of state administration:

"(5) Compensation shall not be denied in such State to any otherwise eligible individual for refusing to accept new work under any of the following conditions: $(A)$ If the position offered is vacant due directly to a strike, lockout or other labor dispute; (B) if the wages, hours, or other conditions of the work offered are substantially less favorable to the individual than those prevailing for similar work in the locality; (C) if as a condition of being employed the individual would be required to join a company union or to resign from or refrain from joining any bona fide labor organization."

Through the powers conferred, the Social Security Board may control the actual operation of state laws. If, in its opinion, there is, either through state administrative or court action, "a denial, in a substantial number of cases, of unemployment compensation to individuals entitled thereto under such law" or if compensation is denied where, in its opinion, "the wages, hours or other conditions of the work" offered are substantially less favorable to the individual than those prevailing for similar work in the locality," it may go far to destroy industry in the state involved, unless there is immediate obedience to its orders. It is true, of course, that notice and an opportunity to be heard are provided with respect to the refusal of federal funds, but this places little limitation upon the wide discretion of the federal body.

Although no abuse is to be expected from the present membership of the Social Security Board, the powers conferred upon it offer great possibilities for the future. An effort has been made to avoid the dominance of one party in the Social Security Board and in certain of the state unemployment compensation commissions, but a non-political administration is not accomplished by representation of two parties, or 
by fairly long and staggered terms of office. Politics has been the most serious single problem in the state administration of workmen's compensation, and the administration in the several states has not consistently been of a high grade, but federal standardization would have reduced all to a common level of mediocrity. Conditions during the past twenty-five years would probably have been much worse had the administration of state compensation laws been under a centralized control in Washington. Greater opportunities present themselves in unemployment compensation, because the issues are less definite and there will, as to most claims, be no party who has a sufficient direct interest to investigate the basis of the claim. The final determination will thus in many cases rest with the manager of a state public employment office. Politics has been dominant in the public employment offices in some states, and perhaps it will not disappear even though opposed both by the Department of Labor and by the Social Security Board. Unfortunately, also, future political influences in the Social Security Board itself are made possible by the provision that "appointments of attorneys and experts may be made without regard to the civil service laws," ${ }^{\prime 2}$ and by the omission to provide any limitations upon the executive power to remove members of the Board. It may be that the members of this Board do not fall within the scope of the recent decision of the United States Supreme Court in Rathbun v. United States, ${ }^{43}$ but there would have been wisdom in attempting to protect them from removal without cause. Unemployment compensation has an uncertain actuarial basis at best; if politics intervenes or if there is a failure of adequate investigation of claims, it will become but an illusive dream to the worker.

In order to obtain a successful administration of unemployment compensation, there must be ( $\mathrm{r}$ ) a sufficient employer interest in each specific claim for compensation; (2) a centralized state control of the machinery designed for action upon claims; (3) a limitation of federal supervision, and a maintenance of state responsibility for the administration of the plan; and (4) an avoidance of conditions which will make possible the use of the plan as an aid to political organizations. In all of these respects a basis for failure has been laid in much that has been done. Experiments must be made in the initiation of any new plan, but mistakes may to some extent be avoided by the anticipation of difficulties that are likely to arise and by the use of knowledge gained from experience with similar problems in the past.

\footnotetext{
12 Social Security Act, supra note I, tit. VII, \$703.

\$ 295 U. S. 602 (1935).
} 